\title{
Central Forest Library Acquisition List No. 60, May 2013
}

Bently, L. and Sherman, B. 2003. Intellectual Property Law. Oxford University Press, New Delhi, 1051p.

Chhokar, K. B., Pandya, M. and Raghunathan, M. 2004. Understanding Environment. Sage Publications, New Delhi, 331p.

Dash, M. C. and Dash, S. P. 2010. Fundamentals of Ecology. Tata McGraw Hill Eduction Private Limited, New Delhi, 562p.

Dubash, N. K. 2012. Handbook of Climate Change and India Development, Politics and Governance. Oxford University Press, New Delhi, 400p.

Gore, A. 2006. An Inconvenient Truth : The Planetary Emergency of Global Warming and What We Can Do About It. Rodale, New York, $325 \mathrm{p}$.

Gupta, M. P. 2009. Crisis Management. Essential Books, New Delhi, 286p.

Gyawali, C. K. 2010. Federalisn in the World. Chandra Kanta Gyawali, Lalitpur, 468p.

Hitchcock, D. and Willard, M. 2006. The Business Guide to Sustainability : Practical Strategies and Tools for Organization. Earthscan. USA Publisher, Washington DC, 292p.

Ingnam, K. 2009. An Introduction to World Trade Organization. Kathmandu School of Law, Bhaktapur, 654p.

Kala, C. P. and Silori, C. S. 2013. Biodiversity Communities and Climate Change. The Energy and Resources Institute (TERI), New Delhi, 330p.

Kaarthikeyan, D. R. 2006. Commentary on Anti - Corruption Laws : With Exhaustive Commentaries on The Prevention of Corruption Act, 1988. Ashoka Law House, New Delhi, 1756p.

Khatiwada, P. P. 2065 B.S. Problem of Human Disappearances in Nepal (A Study With the Solution Measures). Centre For Conflict Studies, Kathmandu, 340p.

Lakshmikanthamma, S. 1997. Sustainability of Dryland Agriculture in India : A Case Study of Watershed Development Approach. MD Publications Pvt. Ltd., New Delhi, 339p.

Miller, R. W. and Donahue, R. L. 1997. Soils In Our Environment. Prentice Hall of India Private Limited, New Delhi, 649p.

Murty, C. and Narayan, S. 2002. Water Resources Engineering : Principles and Practice. New Age International Publishers, New Delhi, 306p.

Majupuria, T. C. and Majupuria, R. K. 2006. Wildlife and Protected Areas of Nepal [Resources and Management] (Most up to date and correct description of Mammals of Nepal together with recent delineation of wildlife Protected Areas, conservation and Management) Opposite Saharanpur Club, Saharanpur (U.P.) India, 549p.

Ojha, E. R. 1999. Dynamics and Development Highland Ecosystems. Walden Book House, Kathmandu, 278p.

Ojha, H. R., Timalsina, N. P., Kumar, C., Banjade, M. R. and Belcher, B. 2008. Communities, Forests and Governance Policy and Institutional Innovations From Nepal. ADROIT Publishers, New Delhi, 247p.

Parks, P. J. 2004. Global Warming : The Lucent Library of Science and Technology. Lucent Books, New York, 112p.

Padma, T. and Rao, K. P. C. The Principles Environmental Studies [Based on Revised Syllabi of 5 Year Law Degree Course]. ALT Publications, Hyderabad, 338p.

Padma, T. and Rao, K. P. C. 2010. The Principles Environmental Law [Based on revised Syllabi of 5 Years Law Degree Course] ALT Publications, Hyderabad, 335p.

Pandit, A. 2010. Watershed Development Inputs and Social Change : Understanding the Changing Culture of Child Nutrition. Rawat Publications, Jaipur, 168p.

Prakash, A., Sarvanan, V. S. and Chourey, J. 2012. Intlacing Water and Human Health Case Studies From South Asia. Sage Publication, New Delhi, 470p. 
Rajagopalan, R. 2011. Environment : An Illustrated Journey. Oxford University Press, New Delhi, 236p.

Roth, D. and Vincent, L. 2013. Controlling the Water Matching Technology and Institutions in Irrigation Management in India and Nepal. Oxford University Press, New Delhi, 400p.

Rao, P. V. 2003. Textbook of Environmental Engineering. Prentice-Hall of India Private Limited, New Delhi, 268p.

Sethi, V. K. 2009. Disaster Management. Essential Books, New Delhi, 325p.

Satyal, Y. R. 2000. Essentials of Tourism. Adroit Publishers, New Delhi, 126p.

Subedi, B. P. 2006. Linking Plant - Based Enterprises and Local Communities to Biodiversity Conservation in Nepal Himalaya. Adroit Publishers, New Delhi, 244p.

Tamrakar, N. K. 2011. Practical Sedimentology. Bhrikuti Academic Publications, Kathmandu, 232p.

\section{$\mathbb{E}[$ Notice}

The Central Forest Library hereby requests all researchers, academicians and students to send one copy of their thesis and research papers related to forestry, wildlife, botany, soil conservation, socioeconomic studies, Medicinal Plants, environment and biodiversity to this library.

\section{Central Forest Library}

Department of Forest Research and Survey,

P.O. Box : 3339, Kathmandu, Nepal

E-mail: info@dfrs.gov.np

Tel. No. 4220482/4269491 